\title{
BEK BULAT: FROM A MILITARY COMMANDER TO A REBEL*
}

\author{
I.M. Mirgaleev \\ Sh.Marjani Institute of History of Tatarstan Academy of Sciences \\ Kazan 420014, Russian Federation \\ E-mail:dilnur1976@mail.ru
}

The article is devoted to Bek Bulat - one of the characters in the Golden Horde history of the end of the $14^{\text {th }}$ century and one of the first traitors during the confrontation between khan Tokhtamysh and Aksak Timur. During this period, the Golden Horde again faced political instability. Bek Bulat was the first and foremost among the contenders to the central power. His figure is interesting because at the beginning of his career, he was one of Toktamysh's military commanders and his relative, but later he betrayed his suzerain. His story helps us to understand Edigu and his supporters. For if Bek Bulat would not be destroyed in 1392, possibly it would have been he who would have become the arbiter of fate in the early $15^{\text {th }}$ century.

Tensions between Tokhtamysh's supporters and opponents were profound. Tokhtamysh proclaimed the revival of the Golden Horde of the times of khans Uzbek and Janibek, but his adversaries opposed Tokhtamysh's policy aimed at centralizing power. They wished to maintain influence of clans in order to prevent beklyaribek and vizier's power to become declarative. To accomplish their goals Tokhtamysh's adversaries tried to use his confrontation with Timur and came into contact with the latter. They betrayed Toktamysh during the decisive battle on Kondurcha in 1391, and later he executed them for this treachery.

Keywords: Golden Horde, Bek Bulat, khan Tokhtamysh, Timur, Saray.

For citation: Mirgaleev I.M. Bek Bulat: From a Military Commander to a Rebel. Golden Horde Review. 2016. Vol. 4, no. 4, pp. 784-789. DOI: 10.22378/2313-6197.20164-4.784-789

In his struggle for power in the Golden Horde since the second half of the 1370s [4], Tokhtamysh eliminated the political turmoil lasted for nearly two decades. We can name the whole complex of problems among the reasons for this turmoil. However, its primary cause was extinguishing of the founding ruling dynasty of the Batuids. Other reasons only exacerbated the crisis. By the end of 1380, Tokhtamysh was able to fully take control over the entire territory of the Golden Horde. With him begins the ruling period of Tuqa-Timurid line of the Jochid dynasty. Although the Shibanids could also prove their rights and even participate in the struggle for the Golden Horde throne and later, to rule in Western Siberia. However, the Tuqa-Timurids ruled in the major Tatar khanates, be it the Crimean or Kazan khanates ${ }^{1}$.

\footnotetext{
* English translation by Roman Hautala.

${ }^{1}$ Also, the Kazakh khans, apparently, were the representatives of one of the branches of the descendants of the youngest son of khan Jochi. Although this issue is still open for discussion. The researchers suggested that the Kazakh khans could be the descendants of the eldest Jochi's son, Orda Ichen, or even the descendants of the Chaghataid dynasty.
} 
However, even after he had finished with turmoil, its echoes disturbed Tokhtamysh's reign. It is known that the main Tokhtamysh's problem was the confrontation with emir Timur. Precisely during his confrontation with Aksak Timur the Golden Horde again faced political instability. Bek Bulat was the first and foremost among the contenders to the central power.

In our work dedicated to the analysis of written and numismatic information on Bek Bulat [3], we have already discussed some of the issues related to Beck Bulat and especially the question of Beck Bulat's identity with Bek Pulad (differences in spelling of this name arose because of some misunderstandings of numismatic and written sources).

Bek Bulat's figure is interesting because at the beginning of his career, he was one of Toktamysh's military commanders and his relative, but later he betrayed his suzerain. Only after Tokhtamysh had been able to eliminate the most prominent opponents from his own Tatar feudal environment in 1392, Timur-Kutlugh and Edigu could rise in the camp of Tatar aristocracy opposed to Tokhtamysh. They were striking and extremely contradictory personalities. Among others, Bek Bulat's story helps us to understand Edigu and his supporters. For if Bek Bulat and his supporters would not be destroyed in 1392, possibly it would have been he who would have become the arbiter of fate in the early $15^{\text {th }}$ century.

Along with the first failures in foreign policy, in the second half of the 1380s, the block of khan Tokhtamysh's opponents consisting of representatives of various clans begins to coalesce into factions and intensify their activities. The economy of the country just began to recover from the troubled times of 1360-70s. In turn, the economic reforms undertaken in the beginning of 1380s had not yet yielded results as very little time had passed since their inception. The war with Aksak Timur demanded great human and material resources and most importantly, it distracted the Golden Horde government from domestic problems.

Despite the strong popularity of the ideology of khan Tokhtamysh's supporters, economic difficulties and initiated failures in foreign policy contributed to the strengthening of opposition-minded factions.

These factions, which opposed to Tokhtamysh and did not accept his ideology having a negative attitude towards his personality, pursued different goals, namely: desire of certain Jochids to become Khan, to change the course of domestic and foreign policy as well as to let loose the rigid centralization. These factions decided to use the Timur's factor in their struggle.

Some fled to Timur hoping to get the throne of the ulus of Jochi with his help [7, p. 143]. Others, like Bek Bulat, used the absence of Tokhtamysh to assert their authority in some regions. Those factions that were already in power and close to khan, sent people to Timur urging him to invade the Golden Horde and promising to raise a rebellion on their part [1, p. 37].

The contradictions between Tokhtamysh's supporters who proclaimed the revival of the Golden Horde "as in the time of khans Uzbek and Janibek" and his opponents who had more mundane goals (as subsequent events showed) were very profound. Tokhtamysh's opponents also had some kind of ideology, since the bitterness between the two parties increased to the point that in mutual struggle Tokhtamysh along with all his sons were killed as well as Edigu himself. Before his death, Edigu with his puppet khans pursued the same objectives in foreign policy as Tokhtamysh did. Therefore, their contradiction based on the treatment of 
domestic issues. In our opinion, these disagreements arose because of Tokhtamysh's excessive aspiration to centralize his power and his desire to rule alone. Perhaps, among these causes it should be also mentioned his desire to consolidate a new ruling dynasty and to secure the succession to his posterity, which would conceal the way to the political Olympus for other Jochid candidates. It is no accident that Tokhtamysh's large family was left without direct descendants from the male line. His opponents from the ruling non-Jochid families wished to maintain influence of clans in order to prevent beklyaribek and vizier's power to become declarative. Exactly the Jochid contenders for the supreme power made their policy convenient.

Precisely this kind of situation contributed to Bek Bulat's appearance on the political stage. Ibn Khaldun speaks about oglan Bulat and calls him as "one of the relatives" of khan Tokhtamysh [8, p. 392]. No doubt, he was a Jochid and belonged to the Tuqa-Timurid line. Perhaps, after the victory over Mamai he received one ulus in the former Horde of the latter. According to Russian chronicles, ulus of oglan Bek-Bulat was located in the upper reaches of the Don [6, p. 96]. Perhaps, some part of the Tatar aristocracy of Ak Horde, from the former supporters of Mamai, united around his figure.

Bek Bulat opposed Tokhtamysh already in the late 1380s [3; 4; 5]. One entry of Massaria Caffae for 1386 already calls Bek Bulat "His Majesty the Emperor" [5, p. 20]. Sharaf al-Din Yazdi mentions Bek Bulat among Tatar commanders sent to capture Tabriz in 1386 году [9, p. 151]. Bek Bulat was one of the commanders of Tokhtamysh who was, in 1388, on the Caucasian front at the head of Tatar troops left there to repel a possible Timur's attack on Shirvan and the Golden Horde territory itself.

In our opinion, when khan Tokhtamysh was on the border of his State in 1389, a group of Tatar feudal lords mutinied in Central Asia and precisely Bek Bulat was at the head of this rebellion.

Shortly after the war with the Empire of Timur had begun in Transcaucasia, a second front was opened in Central Asia. At the end of 1388 - beginning of 1389 , khan Tokhtamysh himself headed troops operated in the Central Asian front. Bek Bulat was at the head of troops remained on the Transcaucasian front. Taking advantage of the Tokhtamysh's absence in the capital, he unexpectedly raised a rebellion, but failed to take the capital and went to the Crimea. Later, however, khan Tokhtamysh forgave (?) him because he was his closest relative. Later he participated in the Battle of Kondurcha against Timur, where precisely his another betrayal prevented Toktamysh to defeat his enemy.

One of the main reasons that forced Tokhtamysh to retreat in spring of 1389 was the need to stabilize the domestic political situation in the Golden Horde, to protect the capital and suppress the rebellion.

It was internal political instability that forced Tokhtamysh to suspend his active confrontation with Timur. While Tokhtamysh was busy with internal problems, Timur conquered Shirvan and, by the end of 1390, his troops came close to the Golden Horde borders in the Caucasus and took control of the Derbent Fortress. Naturally, such a situation forced Tokhtamysh to concentrate some military forces on the Caucasian front. Tokhtamysh expected attack exactly from the Caucasian direction and practically bared eastern frontiers, which was one of the reasons for the defeat in the Battle of Kondurcha. 
In his letter to Jagiello, Tokhtamysh reports to him that Bek Bulat rebelled and left the battlefield in 1391. Tokhtamysh's letter was written in $795 \mathrm{AH}$ (between November 17, 1392 - November 5, 1393). Listing the names of the rebels, among which Bek Bulat's name is also mentioned, Tokhtamysh speaks that this happened "last year" [1, p. 37]. Ibn Khaldun says that oglan Bulat left the battlefield of Kondurcha and attacked Sarai [8, p. 392-393].

According to the Tokhtamysh's letter to Jagiello and such authors as Ibn Khaldun, Sharaf al-Din Yazdi, Mirkhond, Khondemir [1, p. 37; 8, p. 392; 9, p. 168; 11, p. 461, 486], Bek Bulat participated in the battle of Kondurcha on the Toktamysh's side.

Considering that in his letter Tokhtamysh speaks about secret intercourse of the rebels with Aksak Timur [1, p. 37], perhaps they had established a connection with Timur long before this and coordinated their actions with him in the middle of 1380s. During the Tokhtamysh's campaign to Central Asia in 791 AH (between November 31, 1388 - December 19, 1389), uprising of the Serbedars and the Turkmen threatened Timur with loss both of recently conquered Persia and along with it of an access to the Caucasian border of the Golden Horde. Consequently, his secret contacts with the Tokhtamysh's generals become perfectly understandable.

In 1389-90s, khan Tokhtamysh was in a difficult political situation. Therefore, the government made certain concessions in centralizing policy. It is obvious that Tokhtamysh and Bek Bulat found a mutual compromise. It is also possible that Tokhtamysh revised priorities in foreign and domestic policy.

According to the sources, Tokhtamysh suffered defeat "as a result of the Great Emirs' propensity towards Timur-Gurgan" [9, p. 209]. Remarkably, this same reason is mentioned in the official version provided by the Tokhtamysh's government [1, p. 37].

After the defeat at Kondurcha, Tokhtamysh absconded in the Middle Volga, on the northern outskirts of the Bulgar ulus, and when "he regained composure, he gathered his army and called for help his people, who helped him" [8, p. 470], Tokhtamysh very energetically set about the punishment of traitors who "went to the border regions and established themselves there" [8, p. 393]. Already at the beginning of $795 \mathrm{AH}$ (between November 17, 1392-- November 5, 1393) "they were executed so that they do not cause more ... harm" [1, p. 21-22]. This time, Tokhtamysh executed Bek Bulat as well for the fact that he left khan during the battle and attacked the capital declaring himself khan and starting to mint coins in his own name - but as it turned out, for a short while.

\section{REFERENCES}

1. Berezin I.N. Khanskie yarlyki. I. Yarlyk Tokhtamysh-khana k Yagaylu [The Khans' Yarlyks. I. Yarlyk of Tokhtamysh Khan to Jagiello]. Izdanie Kn. M.A.Obolenskogo. Kazan, N.Kokevina Publ., 1850. 72 p. (In Russian)

2. Markov A.K. Inventarnyj katalog musul'manskih monet Imperatorskogo Jermitazha [Inventory Catalog of Muslim Coins of the Imperial Hermitage]. St. Petersburg, 1896. 879 p. (In Russian)

3. Mirgaleev I.M. K voprosu o Bek Bulate - Bek Pulade [On the Question of Bek Bulat - Bek Pulad]. Nauchnyj Tatarstan [Scientific Tatarstan]. 2004, no. 1/2, pp. 145-149. (In Russian) 
4. Mirgaleev I.M. Politicheskaja istorija Zolotoj Ordy perioda pravlenija Toktamyshhana [The Political History of the Golden Horde during the Reign of Tuqtamish Khan]. Kazan, Alma-Lit Publ., 2003. 164 p. (In Russian)

5. Ponomarev A.L. «Solkhatskaya voyna» i «imperator» Bek Bulat [The "Solkhat War" and "Emperor" Bek Bulat]. Zolotoordynskoe nasledie. Is. 2. Materialy vtoroy Mezhdunarodnoy nauchnoy konferentsii «Politicheskaya $i$ sotsial'no-ekonomicheskaya istoriya Zolotoy Ordy», posvyashchennaya pamyati M.A. Usmanova. Kazan', 29-30 marta 2011 g. [Golden Horde Legacy. Proceedings of the Second International Research Conference "Political and Socio-Economic History of the Golden Horde", dedicated to the memory of M.A. Usmanov. Kazan, March 29-30, 2011]. Otv. red. i sost. I.M.Mirgaleev. Kazan, OOO «Foliant», Sh.Marjani Institute of History of Tatarstan Academy of Sciences Publ., 2011, pp. 18-21. (In Russian)

6. Polnoe sobranie russkikh letopisey. Patriarshaya ili nikonovskaya letopis' [Complete Collcetion of Russian Chronicles. Vol. 11-12. Patriarchal or Nikon Chronicle]. Moscow, Nauka Publ., 1965. 520 p. (In Russian)

7. Rodoslovnoe drevo tyurkov". Sochinenie Abdul"-Gazi, Khivinskogo khana [Genealogical Tree of the Türks. Writing by Abdul-Ghazi, the Khan of Khiva]. Perevod i predisl. G.S. Sablukova, s poslesloviem i primech. N.F. Katanova. Kazan, Tipo-litografiya Imperatorskogo universiteta, 1906. 336 p. (In Russian)

8. Tiesenhausen V.G. Sbornik materialov, otnosyashchikhsya $k^{\prime \prime}$ istorii Zolotoy Ordy. Izvlecheniya iz sochineniy arabskikh". [Collection of Materials Relating to the Golden Horde History. Vol. I. Excerpts from the Arab Writings]. St. Petersburg, IAN Publ, 1884. 564 p. (In Russian)

9. Tiesenhausen V.G. Sbornik materialov, otnosyashchikhsya $k^{\prime \prime}$ istorii Zolotoy Ordy. Izvlecheniya iz persidskikh sochineniy sobrannye V.T. Tizengauzenom i obrabotannye A.A.Romaskevichem i S.L.Volinym [Collection of Materials Relating to the Golden Horde History. Vol. II. Excerpts from the Persian Writings collected by V.G. Tiesenhausen and processed by A.A. Romaskevich and S.L. Volin]. Moscow, Leningrad, Akademiya nauk SSSR Publ., 1941. 308 p. (In Russian)

10. Fraehn Ch.M. Resensio numorum Muhammedanorum. Academiae imp. Scient, Petropolitanae inter prima Academiae imp. saecularia edita. Petropoli, Litteris Academicis, 1826. 743 p. (In Latin)

11. Charmoy M. Expédition de Timour-i-Lenk ou Tamerlan contre Toqtamiche, khân de l'Ouloûs de Djoutchy, en 793 de l'hégire ou 1391 de notre ère. Mémoires de l'Académie impériale des sciences de St.-Pétersbourg. $\sigma^{e}$ série, Sciences politiques. Histoire et philologie, vol. III. St. Petersburg, 1836, pp. 89-505. (In French)

About the author: Il'nur M. Mirgaleev - Cand. Sci. (History), Head of the Usmanov Center for Research on the Golden Horde and Tatar Khanates, Sh.Marjani Institute of History of Tatarstan Academy of Sciences (5 entrance, Kremlin, Kazan 420014, Russian Federation). E-mail: dilnur1976@mail.ru

Received September 2, 2016

Accepted for publication November 3, 2016 
Mirgaleev I.M. Bek Bulat: From a Military Commander to a Rebel 789

\title{
БЕК БУЛАТ: ИЗ ПОЛКОВОДЦА В МЯТЕЖНИКИ
}

\section{И.М. Миргалеев}

\author{
Институт истории им. Ш. Марджани АН РТ \\ 420014, Казань, Российская Федерация \\ E-mail:dilnur1976@mail.ru
}

Статья посвящена Бек Булату, одному из персонажей золотоордынской истории конца XIV века и одному из первых предателей во время противостояния хана Токтамыша с Аксак Тимуром. В этот период Золотая Орда вновь столкнулась с политической нестабильностью. Первым и главным среди претендентов на центральную власть выступил Бек Булат. Бек Булат интересен тем, что в начале своей карьеры он был одним из полководцев Токтамыша и был его родственником, но в дальнейшем он предал своего сюзерена. Его история помогает понять Идегея и его сторонников: ведь если не был бы в 1392 году уничтожен Бек Булат, то возможно именно он был бы вершителем судеб в начале XV века.

Противоречия между сторонниками и противниками Токтамыша были глубокими. Токтамыш провозгласил возрождение Золотой Орды как во времена хана Узбека и Джанибека, а его противники выступали против централизаторской политики Токтамыша и хотели сохранить влияние кланов, чтобы власти беклярибека и визиря не были декларативными. Противники Токтамыша хотели использовать в своих целях противостояние с Тимуром и установили с ним связь. Во время решающей битвы на Кондурче в 1391 году они предали Токтамыша, за что он казнил их впоследствии.

Ключевые слова: Золотая Орда, Бек Булат, хан Токтамыш, Тимур, Сарай.

Для цитирования: Mirgaleev I.M. Bek Bulat: From a Military Commander to a Rebel // Золотоордынское обозрение. 2016. Т. 4, № 4. C. 784-789. DOI: 10.22378/23136197.2016-4-4.784-789

Сведения об авторе: Ильнур Мидхатович Миргалеев - кандидат исторических наук, руководитель Центра исследований Золотой Орды им. М.А. Усманова Института истории им. Ш. Марджани АН РТ (420014, Кремль, подъезд 5, Казань, Российская Федерация). E-mail: dilnur1976@mail.ru

Поступила 02.09.2016 г.

Принята к публикации 03.11.2016 г. 